\title{
Dynamic Impact of Unprofitable Cross-buying on Purchase Incidence and Purchase Amount
}

\author{
Makoto Morisada \\ Graduate School of Economics, Osaka University \\ 1-7, Machikaneyama-cho, Toyonaka, Osaka, Japan \\ E-mail: sgm012mm@student.econ.osaka-u.ac.jp
}

Yukihiro Miwa

Graduate School of Economics, Osaka University

1-7, Machikaneyama-cho, Toyonaka, Osaka, Japan

E-mail: sge024my@student.econ.osaka-u.ac.jp

Wirawan Dony Dahana (Corresponding Author)

Graduate School of Economics, Osaka University

1-7, Machikaneyama-cho, Toyonaka, Osaka, Japan

Tel: 81-6-6850-5241 E-mail: dony@econ.osaka-u.ac.jp

Received: Jan. 29, 2018 Accepted: March 25, $2018 \quad$ Published: April 1, 2018

doi:10.5296/jmr.v10i2.12803 URL: https://doi.org/10.5296/jmr.v10i2.12803

\begin{abstract}
This study investigates how unprofitable cross-buying, defined as the tendency to buy different product categories during price promotion, affects consumer decisions of whether and how much to buy in the short- and long-term periods. We utilize a type II Tobit model of purchase incidence and purchase amount and apply the model to purchase history data of an online shopping mall's customers to capture the dynamic impacts of unprofitable cross-buying. The results reveal that unprofitable cross-buying behavior leads to lower purchase probability and purchase amount in the short-term. On the contrary, in the long-term, unprofitable cross-buying behavior appears to have positive impacts on both behavioral outcomes. Additionally, we also discovered the significant effects of customer characteristics
\end{abstract}




\section{Macrothink}

Journal of Management Research

ISSN 1941-899X 2018, Vol. 10, No. 2

and time variables on the extent to which customers engage in this behavior. Theoretical and managerial implications of these findings are discussed.

Keywords: Unprofitable cross-buying, purchase incidence, purchase amount, Tobit model, promotion 


\section{Introduction}

Since the work of Verhoef, Franses, and Hoekstra (2001), numerous studies have been undertaken to investigate the antecedents and consequences of cross-buying behavior. Most studies have consistently confirmed the favorable impacts of cross-buying on various aspects of consumer behavior. Amongst them, Kumar, George, and Pancras (2008) and Reinartz, Thomas, and Bascoul (2008) suggested that cross-buying positively affects purchase frequency and purchase amount. However, a recent study by Shah et al.(2012)revealed that cross-buying behavior of some customers who make excessive demands for customer service, generate revenue reversals for the firm by defaulting on loans or excessively return previously purchased products, spend a limited amount due to small size or share of wallet, and purchase loss-leader products, could lead to a reduction in firms' profitability.

In their analysis, Shah et al.(2012) used a rich dataset from financial service, information technology, and catalog retailer firms to derive generalizable results concerning the consequences of cross-buying behavior of profitable and unprofitable customers. Indeed, the results are intriguing as they provided contradictory findings to the extant literature, suggesting that cross-buying behavior does not always lead to favorable behavioral outcomes. However, the study analyzed the negative impact of unprofitable cross-buying in a static manner, which became a major limitation of the research. Therefore, how consumer behaviors evolve as unprofitable cross-buying changes overtime has remained unexplored. We argue that it is important to capture the dynamic effect of unprofitable cross-buying, given the ample evidence that consumers behavior changes over time depending on their past behavior (e.g., Guadagni \& Little, 1983; Keane, 1997).

In this study, we aim to narrow this gap by investigating the effect of unprofitable cross-buying in the short- and long-term in the context of online shopping malls. Here, we define unprofitable cross-buying as a customer's tendency to buy different product categories during price promotion. Further, we distinguish between short- and long-term unprofitable cross-buying to capture the effects in different time spans. The former is operationalized as the percentage of different product categories purchased on sale in the previous purchase occasion, whereas the latter is measured as the cumulative value of the former since the time of the first purchase. An unprofitable cross-buying behavior is presumed to influence consumer decisions of whether to buy and how much to buy in each purchase occasion. In addition, the present research also explores how the extent of unprofitable cross-buying in each purchase occasion is affected by past experiences, consumer characteristics, and time. Considering this purpose, we employ a type II Tobit model (e.g., Ansari, Mela, \& Neslin, 2008), combined with unprofitable cross-buying occurrence model, and apply the model to purchase history data of an online shopping mall's customers to examine the effects of unprofitable cross-buying on purchase incidence and purchase amount.

The main contributions of the current research are twofold. First, to our knowledge, this study is the first to explore the dynamic effects of unprofitable cross-buying on consumer purchase decisions. We expect to derive a deeper understanding of how consumer decisions evolve over time as a result of the behavior by revealing the underlying mechanism. Second, we 
anticipate that the results will be useful for marketers to improve their targeting strategy of cross-selling initiatives. In particular, the findings could help mall owners or store managers to determine which customer segments to engage in a cross-selling campaign.

We organize the remainder of this paper as follows. In the next section, we review related studies of cross-buying consequences. Subsequently, we describe our research framework and state our hypotheses. Following this section, we describe the statistical model and the data used in the empirical analysis. We subsequently discuss the results of the hypotheses testing along with some implications. Finally, we conclude the paper with certain limitations and a direction for future research.

\section{Literature Review}

\subsection{Cross-buying}

Verhoef, Franses, and Hoekstra (2001) introduced the term "cross-buying" to describe buying behavior of multiple product categories from the same seller. Following this research, numerous subsequent studies attempted to elucidate the potential outcomes of this behavior. The main stream of research consistently reported that cross-buying positively affects purchasing behavior. For example, Venkatesan and Kumar (2004) found that cross-buying behavior has positive impacts on purchase frequency. The positive association was also confirmed in a study byLemon and Wangenheim (2009). In addition to purchase frequency, Reinartz, Thomas, and Bascoul (2008) suggested that cross-buying behavior can induce a higher amount spend by consumers in each transaction.

Another study by Kumar, George, and Pancras (2008) revealed that cross-buying potentially increases the profits obtained from customers who intensely engage in that behavior. This finding is consistent with Hallowell (1996) who discovered that customers who use multiple financial services of a bank tend to yield higher profits than those who only use a single service. Moreover, the positive effect of cross-buying on customer profitability was also found in a study by Kumar, Shah, and Venkatesan (2006).

\subsection{Unprofitable cross-buying}

Despite the considerable support for the positive effects of cross-buying, Shah et al.(2012) found that cross-buying behavior can reduce a company's profits if the customers who engage in the behavior are less valuable. More specifically, those who make excessive demands for customer service, generate revenue reversals for the firm by defaulting on loans or excessively return previously purchased products, spend a limited amount due to small size or share of wallet, or frequently purchase during price promotions, would generate loss for a firm if they actively cross-buy multiple products. This finding has a substantial implication as it warns firms that enticing all customers to cross-buy by using price promotions could lead to a decrease in the firm's profitability.

A recent study by Morisada, Miwa, and Dahana(2018) suggested that the negative effects of promotion-induced cross-buying behavior may vary depending on customers' demographic variables. In other words, the negative effect of promotion-induced cross-buying on purchase 


\section{Ml Macrothink}

frequency was found to be larger for younger than older customers. The authors further confirmed that the negative effect on purchase frequency and purchase amount is larger for male than for female customers.

\section{Analytical Framework and Hypotheses}

\subsection{Research framework}

Figure 1 shows the conceptual framework of this study. As aforementioned, we focus on cross-buying behavior that is induced by sales promotion. Although price promotions have been reported to have immediate effects on consumer purchase intentions (Anderson \& Simester 2003; Jedidi, Mela, \&Gupta, 1999), frequent implementations of such activities may reduce internal reference price in the long-term, which eventually lead to a decline in purchase probability in the subsequent periods (Blattberg, Briesch, \& Fox, 1995; Grewal et al., 1998). In this line, we anticipate the negative effects of unprofitable cross-buying on purchase incidence and purchase amount. This is consistent with the finding of Shah et al. (2012) that cross-buying behavior of deal-prone customers may result in a loss of profit.

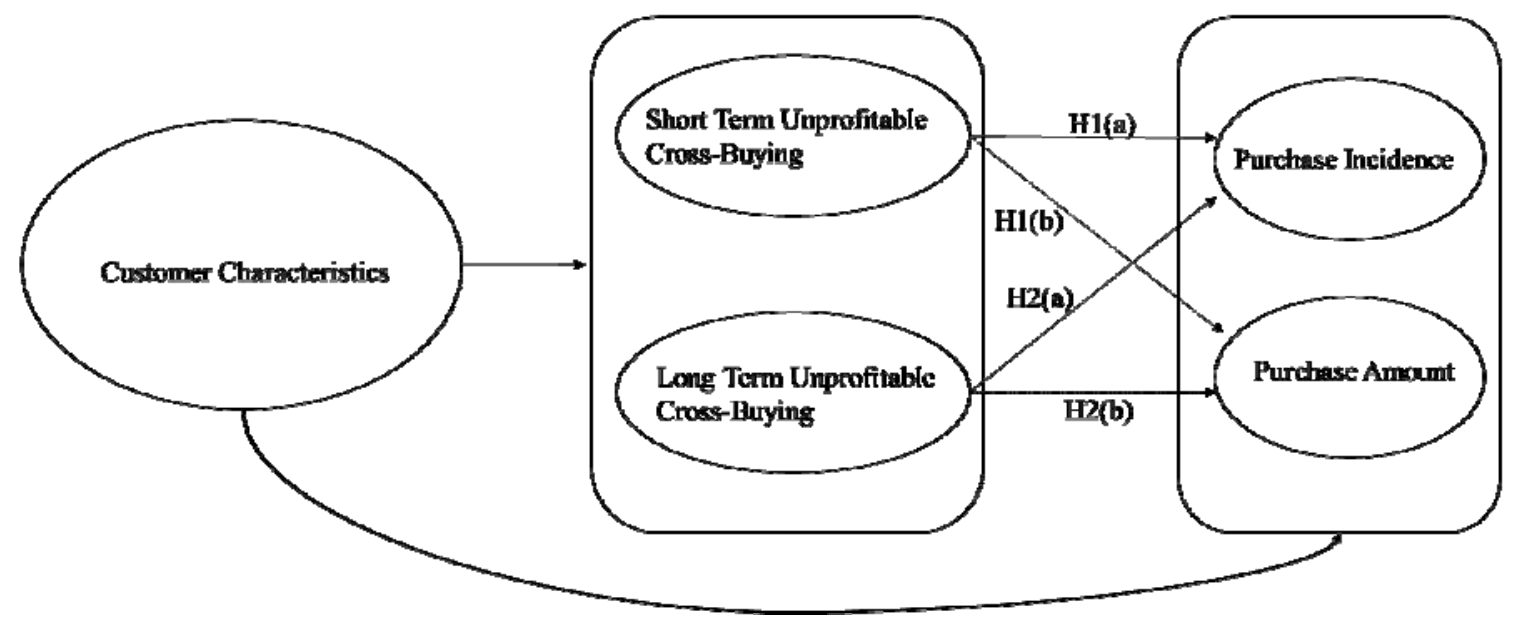

Figure 1. Research Framework

In this study, we extend the work of Shah et al. (2012) by incorporating the short- and long-term effects of unprofitable cross-buying behavior. In so doing, we allow the impacts to depend on past purchase experiences, a commonly used assumption in consumer behavior literature (e.g., McAlister \& Pessemier, 1982; Keane, 1997). The behavioral outcomes considered in this study are purchase incidence and purchase amount. In other words, we examine how past unprofitable cross-buying experiences affect customers' current decision whether to buy, and if so, how much to buy in some stores within a shopping mall. Based on the literature, we build relevant hypotheses concerning the effects of the short- and long-term unprofitable cross-buying, both on purchase incidence and purchase amount decisions. In addition, we also explore how the extent of unprofitable cross-buying engaged by a customer in the current purchase occasion is affected by past cross-buying experiences and other variables. 
Note that we also control for certain customer characteristics that potentially influence buying behavior. First, we include demographic variables, such as age and gender, in the independent variables as these variables have been reported to induce purchase behavior heterogeneity among consumers(Dholakia \& Uusitalo 2002; Van Slyke, Comunale \& Belanger 2002). Further, we account for the potential effect of the type of deviceused by customers to access the mall's website. A recent study by Wang, Malthouse, and Krishnamurthi (2015) suggested that mobile device users tend to buy more frequently than those who use fixed personal computers (PCs) when buying from online stores. Finally, we include the time trend and seasonal effects as, in our data, we observe a concentration of purchases during the New Yearholiday season (i.e., January).

\subsection{Hypotheses}

\subsubsection{Short-term unprofitable cross-buying}

The notion that price promotions increase purchase intention and sales has gained considerable support in the literature (Kuntner \& Teichert, 2016; Jedidi, Mela, \& Gupta, 1999). However, there is indication that although price promotions have positively affected sales in the short-term, the impacts can turn to be negative in the future if implemented too often. Dekimpe, Hanssens, and Silva-Risso(1998) provided evidence that the positive effect of price promotion dissipates overtime. The explanation of this phenomenon is that price promotions lower consumers' internal reference prices (Blattberg, Briesch, \& Fox, 1995; Grewal et al. 1998), and eventually decrease perceived value and purchase intention of a brand (Grawel et al. 1998).

Considering this, it is thus plausible to expect previous unprofitable cross-buying experiences to reduce customers' purchase intentions, leading to a lower purchase probability in the subsequent purchase occasions. Furthermore, lowered internal reference prices should reinforce customers to buy products that are on sale, resulting in lower amounts spent by the customers in each purchase occasion. Hence,

H1(a): Short-term unprofitable cross-buying behavior negatively affects subsequent purchase incidence.

H1(b): Short-term unprofitable cross-buying behavior negatively affects subsequent purchase amount.

\subsubsection{Long-term unprofitable cross-buying}

In the long-term, unprofitable cross-buying behavior may imply different results in comparison to the short-term. In online shopping malls, customers may be loyal to the mall as well as to the hosted stores (Chebat, Hedhli \& Sirgy, 2009; Hedhli, Chebat, \& Sirgy, 2013). Those who are inclined to buy low-priced products would navigate through various stores within a mall to find the best prices. These customers have low store loyalty to a particular store; however, they may have high loyalty toward the mall if they are satisfied with the products sold there. Thus, satisfied customers who frequently engage in unprofitable cross-buying may form favorable attitude toward the mall and turn to be loyal customers in 
the long-term. As suggested by Mela, Gupta, and Lehmann (1997), the difference in purchase amount spent by customers can be explained partially by the level of store loyalty, where loyal customers spend larger amount than disloyal customers. Further, past studies also indicated that loyal customers tend to purchase more frequently than disloyal customers (Dick \& Basu, 1994; Umashankar, Bhagwat, \& Kumar, 2017). Hence,

H2(a): Long-term unprofitable cross-buying behavior positively affects subsequent purchase incidence.

H2(b): Long-term unprofitable cross-buying behavior positively affects subsequent purchase amount.

\section{Model}

We develop a purchase incidence and purchase amount model that captures the dynamic effects of unprofitable cross-buying. In particular, we use a type II model as the analysis involves left-censored purchase amount data (Ansari, Mela, \& Neslin, 2008). In other words, we observe positive purchase amount data when a purchase was made by a customer. We further embed a model of unprofitable cross-buying incidence to the Tobit model to find some influential factors governing customer tendency to cross-buy during price promotion.

Let $b_{i t}$ be an indicator function representing whether or not customer ipurchases at time $t$. Further, we denote the log of the amount spent by $p_{i t}$ if the customer makes a purchase. Denoting the latent utility of making a purchase by $b_{i t}^{*}$, the system equations are given by

$$
\begin{gathered}
b_{i t}=\left\{\begin{array}{cc}
\text { Buy } & \text { if } b_{i t}^{*}>0 \\
\text { No Buy } & \text { if otherwise }
\end{array}\right. \\
p_{i t}=\left\{\begin{array}{cc}
\text { Purchace amount } & \text { if } b_{i t}^{*}>0 \\
0 & \text { if otherwise }
\end{array}\right.
\end{gathered}
$$

The next independent variable is unprofitable cross-buying in purchase occasion $t$, which is denoted byc $b_{i t}$. We operationalize this variable as a percentage of products bought on promotion among all additional products bought by the customer in each transaction.

The utility from buying a product $b_{i t}^{*}$, the amount spent $p_{i t}$, and unprofitable cross-buying $c b_{i t}$, are assumed to be determined by factors such as demographic variables, past unprofitable cross-buying experiences, and time effects. Using the subscripts $b, p$, and $c b$ for purchase incidence, purchase amount, and unprofitable cross-buying respectively, the utility functions of these behaviors are given as follows:

$$
\begin{aligned}
& b_{i t}^{*}=\text { Customer Characteristics }_{b i}+\text { Unprofitable CrossBuy }_{\mathrm{bit}}+{\text { Time } \text { Effect }_{b i t}} \\
& +\mathrm{e}_{\text {bit }} \\
& p_{i t}=\text { Customer Characteristics }_{p i}+\text { Unprofitable CrossBuy }_{p i t}+\text { Time }_{\text {Effect }} \text { pit } \\
& +\mathrm{e}_{\text {pit }}
\end{aligned}
$$




$$
\begin{gathered}
c b_{i t}=\text { Customer Characteristics }_{c b i}+\text { Unprofitable CrossBuy }_{c b i t} \\
+ \text { Time Effect }_{c b i t}+\mathrm{e}_{c b i t}
\end{gathered}
$$

Here, $e_{b i t}, e_{p i t}$, and $e_{c b i t}$ are error terms that follow a multivariate normal distribution, $\mathrm{N}$ $(0, \Sigma)$.

\subsection{Customer Characteristics}

Considering customer characteristics, we include gender, age, and device usage which are available in our database. Letting Int denote the intercept, the effect of customer characteristics is given as follows:

$$
\begin{gathered}
\text { Customer Characteristics }_{b i t}=\text { Int }_{b t}+\beta_{b 1}^{c c} \text { Gender }_{i}+\beta_{b 2}^{c c} \text { Age }_{i}+\beta_{b 3}^{c c} \text { Device }_{i} \\
\text { Customer Characteristics }_{p i t}=\text { Int }_{p t}+\beta_{p 1}^{c c} \text { Female }_{i}+\beta_{p 2}^{c c} \text { Age }_{i}+\beta_{p 3}^{c c} \text { Device }_{i} \\
\text { Customer Characteristics }_{s l i t}=\text { Int }_{c b t}+\beta_{c b 1}^{c c} \text { Female }_{i}+\beta_{c b 2}^{c c} \text { Age }_{i}+\beta_{c b 3}^{c c} \text { Device }_{i}
\end{gathered}
$$

We use a dummy variable for gender that equals 0 if a customer is a male and 1 if otherwise. We use the categorization of Generation X and Generation Y as proposed by Dias(2003) to determine the variable of age. More specifically, we use a dummy variable indicating whether a customer is younger than 35 years old (i.e., Generation Y) or older (i.e., Generation X). We expect to observe different behavioral patterns among customers with different demographic characteristics (e.g., Bakewell and Mitchell 2003; Korgaonkar and Wolin 1999). Finally, the variable for device usage is coded 1 if the customer uses a mobile device and 0 if she or he uses a fixed PC to access the mall's website.

\subsection{Unprofitable Cross-Buying Experiences}

As described previously, we attempt to capture the immediate effect, as well as the cumulative effect of past unprofitable cross-buying experiences on subsequent purchase decisions. Thus, we decompose the experience effects into short- and long-term unprofitable cross-buying as follows:

$$
\begin{aligned}
& \text { Unprofitable CrossBuy }_{b i t}=\beta_{b 1}^{c b} \text { Short Term }_{i t}+\beta_{b 2}^{c b} \text { Long Term }_{i t} \\
& \text { Unprofitable CrossBuy }_{p i t}=\beta_{p 1}^{c b} \text { Short Term }_{i t}+\beta_{p 2}^{c b} \text { Long Term }_{i t} \\
& \text { Unprofitable CrossBuy }_{c b i t}=\beta_{c b 1}^{c b} \text { Short Term }_{i t}+\beta_{c b 2}^{c b} \text { Long Term }_{i t}
\end{aligned}
$$

Here, the short-term unprofitable cross-buying experience is defined simply as the unprofitable cross-buying behavior in the previous purchase occasion, which can be written as 


$$
\text { Short } \operatorname{Term}_{i t}=u c b_{i, t-1}
$$

Further, the long-term unprofitable cross-buying experience is defined as the cumulative unprofitable cross-buying behavior since the first purchase until the most recent purchase occasion.

$$
\text { Long } \operatorname{Term}_{i t}=\sum_{t=1}^{t-1} u c b_{i t}
$$

\subsection{Time Effect}

Additionally, three variables representing the time effects are included in the analysis. First, we include a time trend variable which captures the length of relationship between the customer and the firm. Second, we include a dummy variable for the month when the customers made their first purchase. We anticipate that the purchases in the first moth of the relationship should be driven by different motivations than those in the latter periods. The next variable is the one that captures the seasonality effect. The data used in the analysis indicate a very high level of sales in January, perhaps owing to heavy New Year bargains offered by many stores during this period. Following Ansari, Mela, and Neslin (2008), we create a dummy variable which takes a value of 1 for purchases taking place in January and 0 for those in the other months.

$$
\begin{gathered}
\text { Time Effect }_{b t}=\beta_{b 1}^{t e} t+\beta_{b 2}^{t e} \text { REGISTER }_{\mathrm{i}}+\beta_{b 3}^{t e} \mathrm{JAN} \\
\text { Time Effect }_{p t}=\beta_{p 1}^{t e} t+\beta_{p 2}^{t e} \text { REGISTER }_{\mathrm{i}}+\beta_{p 3}^{t e} \mathrm{JAN} \\
\text { Time Effect }_{s l t}=\beta_{c b 1}^{t e} t+\beta_{c b 2}^{t e} \text { REGISTER }_{\mathrm{i}}+\beta_{c b 3}^{t e} \mathrm{JAN}
\end{gathered}
$$

\section{Data}

In the empirical analysis, we used transaction data of an online shopping mall's customers which were provided by the Joint Association Study Group of Management Science in Japan. There are hundreds of independent stores selling fashion-related products, such as clothes and accessories within the mall. The data comprise of customers' purchase history for a period of 1 year. We observed a large number of customers who purchased multiple product categories in each purchase occasion. For clothing categories, the prices were set high at the beginning of the season, and they were gradually discounted as it got closer to the end of the season (i.e., temporal discounting). The customers appeared to be heterogeneous in price sensitivity; that is, some customers tended to buy products in the early stage of the season when the prices were still high, while the others were more inclined to do so during promotional periods.

The customers in our data also exhibit considerable heterogeneity in terms of purchase frequency. A large number of customers purchased less than 10 times during the study period. However, we also observed a portion of customers with very high purchase frequencies (e.g., 
300 times). We suspected that the high frequency data are likely to be made by business customers and thus decided to discard the "outliers" from the analysis by using the Smirnov-Grubbs test. Further, as we intend to estimate the long-term effect of unprofitable cross-buying which reflects learning behavior of the customers, we limit our focus on newly acquired customers. In particular, we select those who made their first purchase in the online shopping mall during the first 2 months of the study period. The final size of the sample was 500. Table 1 shows the summary statistics of the customers in the data. Based on monthly purchase history, it is shown that the average purchase rate is 0.41 with a standard deviation of 0.151 . The average purchase amount of the customers is 95,434 yen during the year, and the value ranges from 10,000 yen to 820,000 yen. Further, the mean value of the unprofitable cross-buying variables is 0.197 . For customer demographics, the number of male and female customers is 172 and 328, respectively. Further, Generation Y accounted for approximately $60.80 \%$ of the entire sample. Finally, the average rate of mobile device usage by customers to visit the website and make purchases is 0.727 .

Table 1. Summary Statistics of Data

\begin{tabular}{lccccc}
\hline \multicolumn{1}{c}{ Variable } & $\begin{array}{c}\text { Number of } \\
\text { Customers } \\
(\%)\end{array}$ & Mean & Max & Min & SD \\
\hline Purchase Rate & & 0.410 & 0.083 & 1.000 & 0.151 \\
Purchase Amount (yen) & & 95434 & 820000 & 10000 & 93067 \\
Unprofitable cross-buy & & 0.197 & 0.664 & 0.000 & 0.128 \\
Gender & $172(34.40)$ & & & & \\
Male & $328(65.60)$ & & & & \\
Female & & & & & \\
Age & & & & & \\
Generation Y (Age $\leq 35)$ & $304(60.80)$ & & & & \\
Generation X (Age > 35) & $196(39.20)$ & & & & \\
Mobile Device Usage & & & & & \\
\hline
\end{tabular}

\section{Results}

The estimation of the model's parameters was conducted by using Markov Chain Monte Carlo simulation procedure proposed by Ansari, Mela, and Neslin (2008). The chain simulated a set of random numbers from the full conditional distributions of the parameters. We ran 


\section{Macrothink}

Journal of Management Research

ISSN 1941-899X 2018, Vol. 10, No. 2

10,000 iterations and retained the last 5,000 for the inference of the posterior distributions. We confirmed the convergence of the chain by observing the variation of the posterior means.

\subsection{Hypothesis testing}

We show the estimation results in Table2. As can be observed, short-term unprofitable cross-buying has a significant negative impact on purchase incidence $\left(\beta_{b 1}^{c b}=-5.554\right)$, rendering a support for $\mathrm{H} 1$ (a). Similarly, the variable also has a significant negative effect on purchase amount $\left(\beta_{p 1}^{c b}=-12.800\right)$, in support of H1(b). In contrast, we found that long-term unprofitable cross-buying significantly increases the probability that a customer makes a purchase on certain purchase occasions $\left(\beta_{b 2}^{c b}=14.598\right)$, implying a positive relationship between long-term unprofitable cross-buying and purchase incidence. This leads to the acceptance of $\mathrm{H} 2$ (a). Finally, the result revealed that the relation between long-term unprofitable cross-buying and purchase amount is positive and significant $\left(\beta_{p 2}^{c b}=\right.$ 19.439 ),providing a support for H2(b). We summarize the hypotheses testing results in Table 3. 
Table 2. Parameter estimates

\begin{tabular}{lcccccc}
\hline & \multicolumn{2}{c}{ Purchase incident } & \multicolumn{2}{c}{ Purchase amount } & \multicolumn{2}{c}{ UCB } \\
\cline { 2 - 7 } & $\begin{array}{c}\text { Posterior } \\
\text { Mean }\end{array}$ & $\begin{array}{c}\text { Posterior } \\
\text { SD }\end{array}$ & $\begin{array}{c}\text { Posterior } \\
\text { Mean }\end{array}$ & $\begin{array}{c}\text { Posterior } \\
\text { SD }\end{array}$ & $\begin{array}{c}\text { Posterior } \\
\text { Mean }\end{array}$ & $\begin{array}{c}\text { Posterior } \\
\text { SD }\end{array}$ \\
\hline $\begin{array}{l}\text { Independent } \\
\text { variables }\end{array}$ & & & & & & \\
Intercept & $\mathbf{8 . 7 5 7}$ & $\mathbf{1 . 1 8 7}$ & $\mathbf{- 4 . 2 9 3}$ & $\mathbf{0 . 9 6 7}$ & 2.754 & 3.173 \\
Gender & $\mathbf{- 2 . 3 2 2}$ & $\mathbf{0 . 9 5 5}$ & $\mathbf{6 . 5 8 3}$ & $\mathbf{0 . 3 3 0}$ & $\mathbf{- 5 . 3 1 7}$ & $\mathbf{1 . 0 8 7}$ \\
Age & -0.215 & 0.521 & -0.486 & 0.459 & $\mathbf{- 1 0 . 1 8 8}$ & $\mathbf{1 . 0 1 8}$ \\
Mobile & 0.584 & 0.497 & $\mathbf{1 . 3 0 9}$ & $\mathbf{0 . 6 4 5}$ & $\mathbf{- 3 . 3 9 8}$ & $\mathbf{1 . 0 9 5}$ \\
Device & & & & & & \\
Short-term & $\mathbf{- 5 . 5 5 4}$ & $\mathbf{0 . 7 3 9}$ & $\mathbf{- 1 2 . 8 0 0}$ & $\mathbf{1 . 2 1 8}$ & $\mathbf{1 0 . 2 4 8}$ & $\mathbf{1 . 6 7 4}$ \\
UCB & & & & & & \\
Long-term & $\mathbf{1 4 . 5 9 8}$ & $\mathbf{1 . 0 7 7}$ & $\mathbf{1 9 . 4 3 9}$ & $\mathbf{1 . 6 7 9}$ & $\mathbf{- 1 2 . 8 8 2}$ & $\mathbf{2 . 0 2 6}$ \\
UCB & & & & & & \\
Trend & $\mathbf{- 1 . 6 1 2}$ & $\mathbf{0 . 2 4 3}$ & $\mathbf{- 0 . 5 2 4}$ & $\mathbf{0 . 1 0 2}$ & $\mathbf{1 . 1 6 3}$ & $\mathbf{0 . 3 7 6}$ \\
Register & $\mathbf{- 9 . 0 1 3}$ & $\mathbf{2 . 4 1 2}$ & $\mathbf{- 9 . 9 8 9}$ & $\mathbf{2 . 2 6 2}$ & $\mathbf{1 4 . 1 8 9}$ & $\mathbf{5 . 1 0 3}$ \\
January & $\mathbf{1 2 . 7 1 4}$ & $\mathbf{2 . 5 7 6}$ & 0.391 & 2.087 & $\mathbf{- 1 9 . 2 2 8}$ & $\mathbf{3 . 7 5 2}$ \\
\hline & & & & & & \\
\hline
\end{tabular}

Note: Bold fonts indicate significant estimates. $\mathrm{UCB}=$ Unprofitable Cross-Buying

Table 3. Summary of Hypothesis Testing Results

\begin{tabular}{ccccc}
\hline Hypothesis & $\begin{array}{c}\text { Independent } \\
\text { Variable }\end{array}$ & Dependent Variable & $\begin{array}{c}\text { Expected } \\
\text { Direction }\end{array}$ & Result \\
\hline H1(a) & Short-Term UCB & Purchase Incidence & $(-)$ & Supported \\
H1(b) & Short-Term UCB & Purchase Amount & $(-)$ & Supported \\
H2(a) & Long-Term UCB & Purchase Incidence & $(+)$ & Supported \\
H2(b) & Long-Term UCB & Purchase Amount & $(+)$ & Supported \\
\hline
\end{tabular}




\subsection{Drivers of unprofitable cross-buying behavior}

All independent variables (gender, age, mobile rate, short-term unprofitable cross-buying behavior, long-term unprofitable cross-buying behavior, trend, registration, and January) have significant effect on the unprofitable cross-buying behavior. Gender has a negative effect on unprofitable cross-buying, implying that male customers are more likely to engage in the behavior than do female customers. Previous studies suggest that women tend to emphasize the emotional and social-experiential elements of online shopping in comparison to men (Zhou, Dai, \& Zhang, 2007). As price sensitivity could be attenuated by both hedonic and social consumption situations (Wakefield \& Inman, 2003), this may lead female customers to be less price-sensitive than male customers. The estimate of age is negative, which means that Generation $\mathrm{Y}$ tend to cross-buy products on promotion as compared to Generation X. This may be as Generation Y grew up with the computer (Bolton et al. 2013) and purchasing online provides greater benefits (Dholakia \& Uusitalo, 2002). As a result, it would not be challenging for them to compare promotion-induced products in the online shopping mall. Further, mobile device usage has a negative effect on unprofitable cross-buying behavior, indicating that fixed PC users tend to engage in unprofitable cross-buying behavior than mobile device users. While unprofitable cross-buying behavior in the previous purchase occasion (i.e., short-term unprofitable cross-buying behavior) has a positive impact on unprofitable cross-buying behavior, cumulative unprofitable cross-buying behavior (i.e., long-term unprofitable cross-buying behavior)appears to negatively affect the behavior. The estimate of trend and relationship duration are positive, which implies that long tenure customers tend to cross-buy during promotional period than new customers. Interestingly, the percentage of unprofitable cross-buying decreases in January.

\section{Discussion}

In this research, we investigated the effect of short- and long-term unprofitable cross-buying behavior on purchase incidence, purchase amount, and unprofitable cross-buying behavior. We found that short-term unprofitable cross-buying behavior has negative impacts on both purchase incidence and purchase amount. In contrast, long-term unprofitable cross-buying behavior has positive effects on purchase incidence and purchase amount. The results also revealed that while short-term unprofitable cross-buying reinforces such a behavior in the subsequent purchase occasion, the tendency to engage in unprofitable cross-buying dissipates as long-term unprofitable cross-buying increases. As outlined in section 3, this may be as customer loyalty toward the mall increases with purchase experiences, even when customers frequently engage in unprofitable cross-buying.

As for the effect of time trend variable, we found that this variable negatively affects purchase incidence and purchase amount, indicating that the willingness to purchase and to spend a high amount of money gradually decreases as time passes since thetime of membership registration. Further, the dummy for registration month appeared to have a significant negative impact on purchase incidence and purchase amount. We conjecture that it may be owing to the fact that customers have not developed loyalty toward the stores and the 
mall during the period, making them hesitant to purchase products there. Finally, the result revealed that customers tend to purchase in January, as expected.

\section{Implications}

This study has two theoretical implications. First, we extended Shah et al. (2012) by incorporating the dynamic effect of unprofitable cross-buying on customer behaviors which have not been addressed adequately in the literature. Our findings suggest that while short-term unprofitable cross-buying negatively affects purchase incidence and purchase amount, long-term unprofitable cross-buying behavior affect the variables the other way around. We argue that the results contribute to the better understanding of unprofitable cross-buying on consumer decisions. Second, we explored how the tendency of unprofitable cross-buying behavior is affected by past experiences and customer characteristics. The results suggest that unprofitable cross-buying enhances the engagement of the same behavior in the next purchase occasion; however, its cumulative value has the opposite effect in the long-term. The analysis also revealed that the extent to engage in unprofitable cross-buying varies across customers with different demographic characteristics.

Considering managerial implication, the current study may be helpful for managers to better evaluate their customers. As shown by the results, customers who frequently cross-buy products on promotion tend to have lower probability to purchase and spend smaller amount in each transaction. However, in the long-term, these customers may turn to be profitable by purchasing more frequently or spending higher amounts. Thus, it could be misleading if firms evaluate the profitability of their customers only based on their engagement in unprofitable cross-buying in the short-term.

\section{Conclusion}

This study investigated the effect of unprofitable cross-buying on consumer decisions of whether to buy and how much to buy in each purchase occasion. The dynamic effect of the variable was captured by the short-term and long-term effects, which were shown to have different implications on purchase incidence and purchase amount. The analysis also addressed how the extent of the behavior is affected by past experiences and consumer characteristics. We conceive that the findings provide better understanding about the impacts of cross-buying behavior and guide the marketers to better evaluate their customers. However, we note some limitations of this study. First, the focus of this study was limited to unprofitable cross-buying stemming from purchases of products on promotion. However, as shown by Shah et al.(2012), unprofitable cross-buying may be attributed to customers who(1) make excessive demands for customer service, (2) generate revenue reversals for the firm by defaulting on loans or excessively returning previously purchased products, or (3) spend a limited amount due to small size/ or share of wallet. Therefore, future research may consider the other sources of unprofitable cross-buying behavior. As a second limitation, we only considered cross-buying behavior in the fashion product category. The analysis by using data of different product categories is needed to improve its generalizability. 


\section{References}

Anderson, E., \& Simester, D. (2003). Mind your pricing cues. Harvard Business Review, 81(9).

Ansari, A., Mela, C. F., \& Neslin, S. A. (2008). Customer channel migration. Journal of marketing research, 45(1), 60-76. https://doi.org/10.1509/jmkr.45.1.60

Bakewell, C., \& Mitchell, V. W. (2003). Generation Y female consumer decision-making styles. International Journal of Retail \& Distribution Management, 31(2), 95-106. https://doi.org/10.1108/09590550310461994

Blattberg, R. C., Briesch, R., \& Fox, E. J. (1995). How promotions work. Marketing science, 14(3_supplement), G122-G132. https://doi.org/10.1287/mksc.14.3.G122

Chebat, J. C., El Hedhli, K., \& Sirgy, M. J. (2009). How does shopper-based mall equity generate mall loyalty? A conceptual model and empirical evidence. Journal of Retailing and Consumer Services, 16(1), 50-60. https://doi.org/10.1016/j.jretconser.2008.08.003

Dekimpe, M. G., Hanssens, D. M., \& Silva-Risso, J. M. (1998). Long-run effects of price promotions in scanner markets. Journal of econometrics, 89(1-2), 269-291. https://doi.org/10.1016/S0304-4076(98)00064-5

Dick, A. S., \& Basu, K. (1994). Customer loyalty: toward an integrated conceptual framework. Journal of the academy of marketing science, 22(2), 99-113. http://dx.doi.org/10.1177/0092070394222001

El Hedhli, K., Chebat, J. C., \& Sirgy, M. J. (2013). Shopping well-being at the mall: Construct, antecedents, and consequences. Journal of Business Research, 66(7), 856-863. https://doi.org/10.1016/j.jbusres.2011.06.011

Grewal, D., Krishnan, R., Baker, J., \& Borin, N. (1998). The effect of store name, brand name and price discounts on consumers' evaluations and purchase intentions. Journal of retailing, 74(3), 331-352. https://doi.org/10.1016/S0022-4359(99)80099-2

Grubbs, F. E. (1950). Sample criteria for testing outlying observations. The Annals of Mathematical Statistics, 27-58. https://doi.org/10.1214/aoms/1177729885

Guadagni, P. M., \& Little, J. D. (1983). A logit model of brand choice calibrated on scanner data. Marketing Science, 2(3), 203-238. https://doi.org/10.1287/mksc.1070.0331

Hallowell, R. (1996). The relationships of customer satisfaction, customer loyalty, and profitability: an empirical study. International journal of service industry management, 7(4), 27-42. https://doi.org/10.1108/09564239610129931

Hendershott, Patric H., Robert J. Hendershott, and Terrence J. Hendershott (2001). "The future of virtual malls," Real Estate Finance, 18 (1) 25-32.

Jedidi, K., Mela, C. F., \& Gupta, S. (1999). Managing advertising and promotion for long-run profitability. Marketing science, 18(1), 1-22. https://doi.org/10.1287/mksc.18.1.1 
Keane, M. P. (1997). Modeling heterogeneity and state dependence in consumer choice behavior. Journal of Business \& Economic Statistics, 15(3), 310-327. https://doi.org/10.1080/07350015.1997.10524709

Korgaonkar, P. K., \& Wolin, L. D. (1999). A multivariate analysis of web usage. Journal of advertising research, 39, 53-68.

Kumar, V., George, M., \& Pancras, J. (2008). Cross-buying in retailing: Drivers and consequences. Journal of Retailing, 84(1), 15-27. https://doi.org/10.1016/j.jretai.2008.01.007

Kumar, V., Shah, D., \& Venkatesan, R. (2006). Managing retailer profitability — one customer at a time!. Journal of Retailing, 82(4), 277-294. https://doi.org/10.1016/j.jretai.2006.08.002

Kuntner, T., \& Teichert, T. (2016). The scope of price promotion research: An informetric study. Journal of Business Research, 69(8), 2687-2696. https://doi.org/10.1016/j.jbusres.2015.11.004

Lemon, K. N., \& Wangenheim, F. V. (2009). The reinforcing effects of loyalty program partnerships and core service usage: a longitudinal analysis. Journal of Service Research, 11(4), 357-370. https://doi.org/10.1177/1094670508330451

McAlister, L., \& Pessemier, E. (1982). Variety seeking behavior: An interdisciplinary review. Journal of Consumer research, 9(3), 311-322. https://doi.org/10.1086/208926

Mela, C. F., Gupta, S., \& Lehmann, D. R. (1997). The long-term impact of promotion and advertising on consumer brand choice. Journal of Marketing research, 248-261. https://doi.org/10.2307/3151862

Morisada, M., Miwa, Y., \& Dahana, W. D. (2018). Behavioral Impacts of Promotion-induced Cross-buying: The Moderating Roles of Age and Gender. Proceedings of the International Conference on Business and Information, 15(01), 97-113.

Portolese Dias, L. (2003). Generational buying motivations for fashion. Journal of Fashion Marketing and Management: An International Journal, 7(1), 78-86. https://doi.org/10.1108/13612020310464386

Reinartz, W., Thomas, J. S., \& Bascoul, G. (2008). Investigating cross - buying and customer loyalty. Journal of Interactive Marketing, 22(1), 5-20. https://doi.org/10.1002/dir.20106

Roy Dholakia, R., \& Uusitalo, O. (2002). Switching to electronic stores: consumer characteristics and the perception of shopping benefits. International Journal of Retail \& Distribution Management, 30(10), 459-469. https://doi.org/10.1108/09590550210445335

Shah, D., Kumar, V., Qu, Y., \& Chen, S. (2012). Unprofitable cross-buying: evidence from consumer and business markets. Journal of Marketing, 76(3), 78-95. https://doi.org/10.1509/jm.10.0445

Umashankar, N., Bhagwat, Y., \& Kumar, V. (2017). Do loyal customers really pay more for services?. Journal of the Academy of Marketing Science, 45(6), 807-826.https://doi.org/10.1007/s11747-016-0491-8 
Van Slyke, C., Comunale, C. L., \& Belanger, F. (2002). Gender differences in perceptions of web-based shopping. Communications of the ACM, 45(8), 82-86.https://doi.org/10.1145/545151.545155

Venkatesan, R., \& Kumar, V. (2004). A customer lifetime value framework for customer selection and resource allocation strategy. Journal of marketing, 68(4), 106-125. https://doi.org/10.1509/jmkg.68.4.106.42728

Verhoef, P. C., Franses, P. H., \& Hoekstra, J. C. (2001). The impact of satisfaction and payment equity on cross-buying: A dynamic model for a multi-service provider. Journal of Retailing, 77(3), 359-378. https://doi.org/10.1016/S0022-4359(01)00052-5

Wakefield, K. L., \& Inman, J. J. (2003). Situational price sensitivity: the role of consumption occasion, social context and income. Journal of Retailing, 79(4), 199-212. https://doi.org/10.1016/j.jretai.2003.09.004

Wang, R. J. H., Malthouse, E. C., \& Krishnamurthi, L. (2015). On the go: How mobile shopping affects customer purchase behavior. Journal of Retailing, 91(2), 217-234. https://doi.org/10.1016/j.jretai.2015.01.002

Zhou, L., Dai, L., \& Zhang, D. (2007). Online shopping acceptance model-A critical survey of consumer factors in online shopping. Journal of Electronic commerce research, 8(1), 41. 